\title{
Metastatic Colon Adenocarcinoma
}

National Cancer Institute

\section{Source}

National Cancer Institute. Metastatic Colon Adenocarcinoma. NCI Thesaurus. Code C160819.

An adenocarcinoma that arises from the colon and has metastasized to another anatomic site. 